\title{
$\mathrm{ANP}$ 의 $\mathrm{BCR}$ 모델에 기반한 교육행정정보시스템(NEIS) 학부모서비스의 수용 활성화 방안 연구: 초등학교 학부모를 대상으로
}

\author{
서 현 식 ${ }^{+}$송 인 국 $^{++}$
}

요 약

\begin{abstract}
본 연구의 목적은 교육행정정보시스템(NEIS)이 제공하는 학부모서비스의 혜택, 비용, 위험 등이 어느 수준일 때 학부모들이 해당 서비스 혹 은 다른 대안을 선택하게 되는지 파악함으로써 대국민서비스인 NEIS 학부모서비스의 활성화 전략을 제시하고자 함에 있다. 대국민서비스 강화 의 일환으로 학부모들의 정보욕구를 해소하고자 시작된 NEIS 학부모서비스는 자녀의 교육관련 정보를 제공할 뿐만 아니라 각종 교육정책에 학 부모의 적극적인 참여를 유도하고 있다. 하지만 최근 NEIS는 성적처리 오류로 인한 대규모 정정 사태, 접속장애 등으로 언론의 집중조명과 일 선교사 및 학부모들로부터 질타를 받고 있다. 더불어 학구적인 측면에 있어서도 NEIS의 수용 활성화를 위한 연구는 교사의 입장에서 기존의 기술수용모형(TAM)을 적용한 연구가 주를 이루고 학부모들이 선호하는 서비스 내용에 대한 연구가 부족한 실정이다. 이에 $\mathrm{ANP}$ 의 $\mathrm{BCR}$ 모델 에 따라 NEIS가 제공하는 학부모서비스를 혜택, 비용, 위험 등으로 분류하고 이들 간에 학부모들이 고려하는 우선순위를 확인하였으며, NEIS 외에도 선택 가능한 대안들에 대한 선호도를 비교 연구하였을 뿐만 아니라 민감도 분석결과도 제시하였다. 본 연구를 통해 학부모들이 NEIS 학부모서비스를 잘 활용하지 않고 있으며 또한 자신들이 선호하는 의견을 해당 서비스가 충분히 반영하지 못하고 있음을 알게 되었다. 이에 NEIS 학부모서비스에 대한 학부모의 수용 활성화 방안을 모색하고자 하였다.
\end{abstract}

키워드 : 교육행정정보시스템, 학부모서비스, ANP, BCR Model, 민감도 분석, 기술수용모형

\section{A Study on Acceptance Vitalizations Plans of NEIS Parents Services Based on ANP BCR Model: Targeting Elementary School Parents}

\author{
Hyun-Sik Seo ${ }^{+} \cdot \operatorname{In}-K u k$ Song ${ }^{++}$
}

\begin{abstract}
The study aims to examine the service preference between the NEIS(National Education Information Systems) and alternatives, based on the benefits, costs and risks of NEIS service for parents, and finally propose the vitalizations plans for that public services. As a part of public services, NEIS has not only provided the educational information for the students, which enables school parents to suffice for information need, and but also leaded in the parents' participation for the various educational policies. However, major NEIS users such as teachers and parents recently began to blame for the various data errors and connection failures of NEIS. Despite of the research importance, most of NEIS studies severely depended on TAM and researches investigating the preference of school parents for NEIS services rarely exist. The study classifies NEIS parents services into benefits, costs, and risks based on ANP BCR model, identifies the preference for the services, compares the NEIS services and alternatives, and provides the results of sensitivity analyses. The analyses identify that NEIS was not frequently used by school parents and that the service preference of the school parents was not considered yet. Consequently, the study stresses the acceptance vitalizations plans for NEIS.
\end{abstract}

Keywords : National Education Information Systems for Parents, ANP, BCR Model, Sensitivity Analysis, TAM

\section{1. 서 론}

† 정 회 워: 단국대학교 경영학부 시간갓사

꺼 정 회 원: 단국대학교 경영학부 부교수(교신저자) 논문접수: 2011년 9월 5일

수 정 일 : 1차 2011년 9월 29일

심사완료 : 2011년 9월 29일
최근 차세대 NEIS(National Education Information System; 교육행정정보시스템) 서비스에서 성적 처리 기능에 오류가 생겨 중·고등학교 학생 2만9천여 명의 내신 성적을 
정정하는 초유의 사태가 빚어진바 있다[1]. 시행 초기부터 접속장애와 함께 학생들의 정보를 입력할 때 처리가 제대로 되지 않는 등 일선 학교 교사들은 물론 학부모들로부터 문 제점이 지적되었던 차세대 NEIS는 '차세대'란 말이 무색할 정도로 잦은 오류가 발생한 바 있다.

$\mathrm{NEIS}$ 가 제공하는 서비스 중 학부모서비스는 학생들의 성 적 및 학교생활 기록 등의 정보를 학부모들이 확인할 수 있 도록 마련한 대국민서비스의 일환으로 학부모 입장에서는 학교와 교사에 대한 불신 해소 및 자녀의 학교생활에 대한 관심과 지원이 제고되고, 학생의 일탈 행동을 사전에 예방 하는 등의 효과가 있을 것으로 기대되었다[2]. 더욱이 여성 들의 사회진출이 활발해지면서 학부모와 학교 간의 의사소 통에 시공간적인 제약을 받고 있기 때문에 NEIS와 같은 정 보시스템은 학부모의 교육 참여를 보장하게 한다는 점에서 많은 관심을 받아왔다.

그러나 일반적으로 학부모는 컴퓨터 및 인터넷을 전문적 으로 사용하거나 다루지 않고 있으며, 단순 인터넷 사용 또 한 학교 자체에서 구축 및 제공하고 있는 홈페이지 사용에 한정되는 경우가 많다. 일명 학교 홈페이지 내에 있는 학급 미니홈피라는 곳으로 학부모들은 해당 사이트를 통해 알림 장을 열람하여 자녀의 과제를 확인한다거나 준비물을 준비 하고, 담임교사가 제공하는 교과학습정보 및 사진 열람 정 도에 그치고 있다. 게다가 NEIS 서비스를 이용하기 위해서 는 학부모들이 공인인증서 준비, 학부모서비스 접속, 해당 교육청 접속, 공인인증서를 이용한 로그인, 학부모서비스 신 청, 학교에서 부모여부 확인 후 승인, 자녀 정보 열람이라는 단계를 거쳐야 한다[3]. 이 과정에서 학부모서비스 신청에 필요한 공인인증서 발급 절차의 문제, 학부모서비스를 통해 제공되는 자료의 오류 및 실시간 갱신의 문제, 학부모들의 관심과 가입률이 낮은 수준에 머물고 있어 학부모서비스 확 산 및 활용에 큰 걸림돌로 작용하고 있다[2, 4]. 그 외에도 김수구[5]는 학부모서비스에 대한 학교와 교사의 무관심으로 인한 승인지연, 학교와 교사에게 양질의 학부모서비스를 요 청하지 못하는 상황 때문에 학부모서비스에 대한 학부모의 인식이 부정적으로 변화하고 있음을 지적하였다.

그럼에도 불구하고 NEIS의 수용에 관한 연구는 교사의 입 장에서 기존의 기술수용모형(TAM; Technology Acceptance Model)을 적용한 연구가 이루어지고 있으며[6], 더군다나 학 부모 입장에서의 연구는 NEIS가 제공하는 정보에 대한 필 요성 등에 대한 단순 인식정도만을 확인하는데 그치고 있다 [7]. TAM 모형 적용의 경우에는 정보시스템 수용이 자율적 인 환경에서 지각된 유용성과 용이성만을 살피는 연구에는 적합하다. 그러나 NEIS의 대국민서비스를 위한 정보시스템 과 같이 특정 교육관련 정보를 얻고자 하는 경우에는, 그리 고 오늘날 우리 사회에서 여성의 사회진출이 일반화되어 내 자녀의 교육 참여에 시·공간적 제한을 받게 되는 경우에는 실질적으로 해당 시스템을 사용하지 않으면 안되기 때문에 자율적 환경의 정보시스템이라 일컫기 힘들다. 그렇다고 해 서 Seddon[8], Goodhue와 Thompson[9], Rai 등[10]의 연구
에서와 같이 해당 시스템을 반드시 사용해야만 하는 강제적 시스템도 아니다. 대국민서비스의 성격상 반드시 NEIS의 학 부모서비스를 이용하지 않는다 하더라도 학교방문 등과 같 은 대안을 통해 해결할 수 있기 때문이다. 이러한 경우, Kim과 Son[11] 그리고 Bendapudi와 Berry[12]의 연구에서 와 같이 정보시스템의 사용은 필요하지만 다른 대안을 선택 할 수 있는 경우가 발생한다. 다만 다른 대안을 선택함으로 써 높은 전환비용을 지불해야 한다. 그러나 해당 시스템을 활성화하기 위해서는 이들 전환비용보다 높은 혜택을 제공 해야 함은 당연하다. 이에 본 연구를 통해 대국민서비스를 지원하는 정보시스템의 성격은 정보격차 등의 해소를 위해 서라도 다른 대안이 주어지는 특성이 있는 것으로 파악한 다. 즉 시스템의 사용이 자율적이거나 강제적이 아닌 경우 로 대국민서비스의 수용을 활성화하기 위해서는 해당 시스 템이 제공하는 혜택이 다른 대안 선택에 따른 전환비용의 부담보다 커야 할 것이다.

한편 ANP(Analytic Network Process)의 BOCR(Benefits, Opportunities, Costs, Risks) 혹은 $\mathrm{BCR}$ 모델[13]은 정책, 비 즈니스 등 다양한 분야에서의 의사결정에 필요한 핵심으로 특정 사안에 대한 혜택, 기회, 비용, 위험 등을 종합적으로 따져야 하는 메커니즘을 설명하고 있다. 이중 혜택은 TAM 모형에서의 유용성에 해당되는 내용이며, 비용과 위험은 Kim과 Son[11] 그리고 Bendapudi와 Berry[12]의 전환비용 을 상승시키는 요인에 해당되는 내용이므로, 본 연구에서는 $\mathrm{ANP}$ 의 $\mathrm{BCR}$ 모델을 적용하는 방법론을 적용함으로써 대국 민서비스 활성화 방안을 제시하는 것이 가능하다.

따라서 본 연구의 목적은 학부모들이 NEIS가 제공하는 학부모서비스의 혜택, 비용, 위험 등이 어느 수준일 때 해당 서비스를 이용 혹은 다른 대안을 선택하게 되는지 파악함으 로써 대국민서비스인 NEIS의 학부모서비스 활성화 전략을 제시하고자 함에 있다. 이를 위해 학부모들이 선택할 수 있 는 대안을 'NEIS에서 제공하는 학부모서비스의 활용', '각급 학교에서 구축한 홈페이지(미니 홈피 등 포함) 이용', '학교 혹은 담임교사 직접방문' '학부모 모임 참여' 등과 같이 설 정하였으며, NEIS의 학부모서비스 이용에 대한 혜택, 비용, 위험 정도에 따라 어떤 대안을 선택하는지 살펴보고자 한 다. 또한 NEIS의 학부모서비스가 제공하는 정보 중에는 내 자녀의 성적, 출결사항과 같은 정보를 열람할 수 있는 혜택 이 주어짐에도 불구하고 NEIS 가입 및 이용에 따른 비용, 시간, 절차상의 부담 등의 정도에 따라 이용을 꺼리게 되는 수준을 민감성 분석을 통해 평가하게 된다.

\section{2. 관련 연구}

대국민서비스를 지원하는 정보시스템의 수용을 향상시키 는 연구경향을 살펴 문제점을 확인하고 대안을 모색한다. 또한 대국민서비스의 특징적 차이를 도출하여 본 연구의 대 상시스템인 NEIS의 학부모서비스 활성화 방안에 적용하여 살펴본다. 


\section{1 대국민서비스 정의 및 수용관련 연구경향}

대국민서비스란 정부부처의 고유한 업무의 수행과 사업실 행을 지원하는 서비스 분야로 정부부처의 대국민 업무 및 사업목적에 부합하고, 업무 규칙 및 절차를 포함한 서비스 분류체계이다. 대국민서비스 분야는 주민생활, 환경, 국가인 프라, 지식활동, 사회복지, 국민건강, 해외·남북교류, 경제활 동, 문화생활, 공공안전 서비스 등을 포함하게 된다[14].

한편, 지금까지는 사용자의 기술수용에 관한 연구로 $\mathrm{TAM}$ 모형이 정보시스템을 이용하는 사용자들을 대상으로 하여 사용자들의 기술수용 및 사용 행태를 설명하는 연구모 형으로 설명되어왔다. TAM 모형은 Davis[15]에 의해 제안 되었으며, 이후 다양한 분야에 걸친 여러 연구자들에 의해 정보기술의 이용이나 수용에 대한 이해를 얻기 위한 방법으 로 활용되어왔다. TAM에 의하면 기술의 수용 여부는 그 기술을 사용할 의도(Intention)에 의해 결정되며, 이러한 기 술 사용의도의 존재 유무는 그 해당 기술이 유용한지와 사 용함에 용이한지를 인지하고 있느냐에 따라 결정된다[15, $16,17,18,19,20]$.

기존 대국민서비스 정보시스템 수용과 관련된 연구들 역 시 TAM 모형이 적용되어 왔다. 예컨대, 하영수[21]는 전자 정부의 구현과 수용성이 밀접한 관계가 있음을 Davis[15]의 $\mathrm{TAM}$ 모형을 중심으로 분석하였다. 즉 사용자들이 전자시스 템을 이용하여 민원처리를 할 때 그 시스템의 이용을 유용 하다고 느끼고, 그 사용방법이 쉽고 친근하다고 여길수록 전자시스템에 대하여 긍정적인 태도가 형성된다고 주장하였 다. 이렇게 형성된 긍정적인 태도는 민원해결에 있어 전자 시스템을 이용하려는 의도를 증가시키고, 그 결과 전자정부 구현에 일조할 것이라는 가설을 제시하고 설문 및 구조분석 을 통하여 주민의 수용성이 향상되었을 때 전자정부 실현에 대한 성과를 확보할 수 있음을 설명하였다. 또한 박정주[6] 는 학교조직의 교육행정정보시스템인 NEIS의 수용 요인에 대한 구조적 분석을 통해 TAM이 경영정보 분야뿐만 아니 라 교육학 분야에서도 적용될 수 있는 모델임을 밝혔다. 즉 지각된 유용성과 용이성이 높을수록 그 기술에 대한 사용의 도가 높아지고, 지각된 용이성이 높을수록 지각된 유용성 또한 높아지는 것으로 나타났다. 이는 기술수용 모델의 주 요 변수인 지각된 유용성과 용이성이 현장 교사가 NEIS를 수용하는 데 있어 가장 중요한 영향을 미치는 변수임을 의 미하며, 이러한 시스템을 사용하기 쉽다고 생각하면 업무에 유용하다고 믿게 되고 그 유용함에 대한 믿음이 강할수록 시스템을 쉽게 받아들이게 되는 것이다.

\section{2 대국민서비스에 대한 TAM 적용의 한계성 및 대안}

$\mathrm{TAM}$ 모형은 정보시스템의 수용이 자율적 환경 하에서 지각된 유용성과 지각된 사용 용이성만을 살피는 연구에 적 합하며, 이용자의 태도에 중요한 영향을 미치는 사회적 요 소 등과 같은 외생변수에 대한 설명은 부족하다[22]. 또한 강제적 상황 하에서 도입된 정보시스템은 최종 이용자가 정 보시스템 사용에 대한 선택권이 없고, 사용할 정보시스템이
이미 정해져 있어 '행동의도', '사용’과 같은 변수가 큰 의미 가 없다는 지적이 끊임없이 제기되어왔다[23]. 김태구[24] 역 시 정보시스템이 이미 정해져 있는 환경에서는 이용자의 비 자발적 의지에 대한 $\mathrm{TAM}$ 의 적용을 정확히 예측할 수 없음 을 지적하였다. 즉, 자발적인 정보시스템을 사용할 경우 개 인의 지각과 느낌이 반영되어 사용에 차이가 발생하며 이에 대한 예측이 가능하지만, 비자발적인 정보시스템을 사용할 경우 이용자의 정보시스템 사용 차이를 발견할 수 없게 되 어 TAM에서의 주요변수인 개인의 유용성과 용이성은 의미 가 없어지게 된다. 또한 강제적 시스템의 경우에는 Ajzen[25]의 TPB(Theory of Planned Behavior), Taylor와 Todd[17]의 DTPB(Decomposed TPB) 모델에서와 같이 $\mathrm{TAM}$ 에서의 인지된 유용성 및 용이성 이외에도 주관적 규 범과 지각된 행동통제에 영향을 미치는 변수들이 추가되어 $\mathrm{TAM}$ 모형에 비해 수용에 관한 설명력을 더욱 높이는 연구 가 이루어지고 있다. 이에 대국민서비스를 지원하는 정보시 스템의 경우 수용을 활성화할 수 있는 적용 가능한 대안을 모색할 필요가 있다.

대국민서비스의 경우 이를 지원하기 위한 정보시스템은 자녀교육 관련 특정 정보를 얻고자 하는 학부모와 학교에 직접 찾아갈 수 없는 맞벌이 가정의 경우 시·공간적 제약이 따르기 때문에 필요한 경우 NEIS에 가입하여 대국민서비스 를 받아야 한다. 이러한 경우 NEIS는 자율적으로 선택하게 되는 시스템이 아니며, 그렇다고 해서 NEIS 학부모서비스를 이용하지 않는다고 하더라도 가능한 경우 학교에 직접방문 혹은 학교 홈페이지 방문 등을 통해 필요한 정보를 취득할 수도 있기 때문에 강제적 시스템의 성격도 아니다. 정보격 차 회피를 위해 자녀의 정보를 학교 등에서 직접 얻을 수 있으나 여건상 기회비용이 적은 대국민서비스를 지원하는 정보시스템의 사용을 이끌고 있다. 그러므로 이들 대국민서 비스를 지원하는 정보시스템의 성공은 이들이 주는 혜택이 나 기회가 비용이나 위험보다는 커야 함을 의미하게 된다. 특히 혜택이나 기회는 TAM 모형에서 제시하는 유용성과 상관관계가 높고 비용이나 위험은 $\mathrm{Kim}$ 과 $\mathrm{Son}[11]$, Bendapudi와 Berry[12]의 전환비용 개념에 가깝다. 이들 요 소간의 상호관계를 따질 수 있는 체계적 방법론으로는 $\mathrm{ANP}$ 의 $\mathrm{BCR}$ 모델이 있다.

\subsubsection{Dual Model에서의 전환비용}

Bendapudi와 Berry[12]는 고객이 특정 서비스를 이용할 때 고객이 원해서 사용할 수도 있지만, 다른 선택적 옵션이 없기 때문에 이용할 수 있음을 설명하였다. 예컨대, 조직에 속한 구 성원들이 회사와 자신의 직무에 만족하지 않더라도 회사를 그 만두지 않는 것은 이직만이 최선의 선택이 아니기 때문이다. 같은 논리로 Bendapudi와 Berry[12]는 고객과의 관계에 대하 여 고객이 원치 않는 상황 하에서도 서비스 제공업자와의 관 계를 유지하려고 하는 Constraint 기반과 제공되는 서비스에 진심으로 감사해 하며 관계를 유지하려고 하는 Dedication 기 반의 관점으로 분할하는 Dual Model로 설명하였다. 
Kim과 Son[11]은 정보시스템 관점에서 Bendapudi와 Berry[12]의 모델을 분석하여 수용 이후의 고객의 행동에 중점을 두어 설명하였다. 즉, Bendapudi와 Berry[12]가 제시 한 Dedication과 Constraint 기반의 고객 관계를 정보시스템 에 만족하는 Dedication 기반의 관계에 있는 고객과, 그리고 거래비용을 최소화하기 위해 어쩔 수 없는 상황에서 정보시 스템을 이용하게 되는 Constraint 기반의 관계로 나누어 설 명하였다. 이는 정보시스템 도입 이후 정보시스템을 직접 이용하는 고객들은 자발적인 상황에서 정보시스템을 사용하 는 것인지 아니면 다른 선택적 옵션이 없기 때문에 어쩔 수 없이 사용하는 것인지 알기 위해서이다. 먼저 Dedicaton 관 점에서는 고객이 원하는 서비스를 제공함으로써 지각된 유 용성을 높여야 하고, Seddon[8]이 제시한 것과 같이 제공된 서비스에 대하여 사용자 만족이 이루어져야 한다. 그 결과 고객의 지속적인 정보시스템 이용에 영향을 주게 되며, 서 비스 제공업자는 이를 통해 고객의 니즈에 맞춘 서비스에 대한 투자를 확대함으로써 지속적인 사용의도를 갖는 환경 을 만들게 된다. Constraint 관점에서는 고객의 전환비용 (Switching Cost)을 높이게 된다. 전환비용은 크게 거래비용 (Transaction Cost), 학습비용(Learning Cost), 인위적 전환 비용(Artificial Switching Cost) 등이 있다[26, 27]. 전환비용 이 높아지면 지속적으로 서비스를 이용할 수밖에 없으므로 현재의 시스템을 계속해서 사용하게 된다.

한편 Rai 등[10]은 비자발적 시스템의 성공 개념을 설명 한 Seddon[8]의 모형을 실증분석하면서 통합학생정보시스템 (Student Information System; 이하 SIS)을 이용하는 대학 교의 교수 및 직원들을 대상으로 연구하였다. 그러나 교수 및 직원들은 정보시스템을 통하지 않고 대학본부의 담당자 를 직접 찾아 자신의 업무를 볼 수 있음에도 불구하고 SIS 의 정보이용으로부터 얻게 되는 혜택과 기회비용으로 인해 해당 시스템을 사용하게 됨을 설명하였다. Kim과 $\mathrm{Son}[11]$, Bendapudi와 Berry[12]의 전환비용 역시 인터넷 서비스 제 공업자와 소비자와의 관계를 따진 것으로 특정 시스템의 사 용을 강제하는 것은 아니지만 소비자는 여러 인터넷 서비스 중에서 전환비용의 이해관계에 따라 특정 시스템을 사용하 게 됨을 설명하고 있다. 이들 모델은 모두 다른 대안의 선 택이 가능하지만 실질적으로 해당 정보시스템을 사용할 수 밖에 없는 현상은 전환비용 등과 같은 기회비용 때문인 것 으로 설명하고 있다.

\subsubsection{ANP 및 BCR Model}

$\mathrm{ANP}$ 는 의사결정 수준과 요인들 간의 복잡한 상호관계를 이용한 의사결정을 모델링한다. 이는 의사결정의 각 범주 (Cluster)에 속한 요인(Elements)들과 다른 범주에 속한 요 인들 간에 상호 작용을 종합적으로 살펴보는 체계이다. 즉, 하나의 의사결정 시스템은 그 하위의 범주들로 표현되며 이 범주들에는 다시 여러 요인들로 구성되는 체계이다[13].

기존 $\mathrm{AHP}$ 와는 다른 주요 차이점은 의사결정 시스템의 구성체계를 네트워크로 묘사하는 방법에서 나타난다. AHP
는 요인들이 단일방향 계층관계로 표현되어 의사결정을 모델링한다. 그러나 현실적으로 의사결정 문제는 관련된 요인간의 상호작용과 종속성이 존재하기 때문에 단순히 단일방향의 계층적 구조로만 설명하기에는 한계가 있게 된다. $\mathrm{ANP}$ 는 바로 이러한 한계를 극복하기 위해 범주 및 요인들 간의 복잡한 상호관계를 분석하는 것으로 Saaty[13] 교수에 의해 개발되었다. 즉, 의사결정 과정상의 각 범주 및 계층 간에, 혹은 같은 계층 안에서도 상호의존 성(Interdependence)을 확인함으로써, 현실 세계에 더욱 정 확한 접근을 통한 복잡한 의사결정 문제 해결을 위한 최적 의 해를 제시해준다[28].

일반적으로 $\mathrm{ANP}$ 를 사용하여 의사결정을 모델링하는 절 차는 일반적으로 다섯 단계에 의해 수행된다[29, 30]. 첫 번 째 단계는 목표 (Goal)와 요인(Factor)들의 상호종속성과 피 드백을 포함하는 의사결정 네트워크 모형을 구축하는 것으 로 시작된다. 두 번째 단계는 요인들 간의 쌍대 비교를 한 다. 선호도는 $\mathrm{AHP}$ 에서와 같이 표준화된 9점 척도를 이용한 다. 세 번째 단계에서는 두 번째 단계의 상호의존성에 대한 쌍대 비교 행렬로부터 요인들 간의 상대적 중요도를 산출한 다. 네 번째 단계는 네트워크상의 모든 요인들을 매트릭스 의 행과 열에 배치하여 각 요인의 중요도를 열(Column) 벡 터로 하는 Supermatrix를 작성한다. 다섯째 과정은 Supermatrix 각 요인들의 가중치가 수렴하여 안정을 유지할 때까지 무한멱승을 수행한 후 요인들의 최종 상대적 중요도 를 결정한다[31]. 이 때, 각 열 벡터들의 합은 1 이 되도록 정 규화 한다[13].

$\mathrm{ANP}$ 를 개발한 Saaty 교수는 자신의 모델을 행정, 경제, 군사 등 여러 정책결정 과정에 적용할 수 있음을 보여주었 으며[13], 특히 BOCR(Benefits, Opportunities, Costs, Risks) 혹은 Opportunities가 제외된 $\mathrm{BCR}$ 모델을 적용할 수 있음을 예를 들고 있다. 예컨대, 자동차 구매를 고려하고 있는 소비 자가 비용(Costs) 및 위험(Risk) 등 부분적 측면에서는 여러 대안 중, 상대적으로 더욱 저렴하고 안전한 미국형 자동차 를 선호하면서도 자동차가 주는 혜택(Benefits)에 대해서는 유럽형 자동차를 가장 선호하고 있다고 가정해본다. 그러나 소비자가 전반적으로는 혜택 범주에 대해 비용 및 위험보다 큰 가중치를 두고 있기 때문에 결과적으로는 유럽형 자동차 를 선택하게 되는 메커니즘은 $\mathrm{ANP}$ 방법론을 적용하여 설명 이 가능해진다. 이에 본 연구에서도 Saaty[13]의 $\mathrm{BCR}$ 모델 을 적용하여 대국민서비스의 수용에 대한 혜택, 비용, 위험 측면을 도출하고자 한다.

\section{3 연구대상인 교육행정정보시스템(NEIS)}

정보통신기술의 발전과 초고속 인터넷의 보급으로 교육현 장의 정보 인프라 구축을 통한 정보관리의 효율성을 높이고, 교육행정기관 및 전국 초·중·고등학교와 특수학교를 인터넷 으로 연결한 첨단 행정정보망의 도입을 위하여 NEIS 서비 스가 시행되었다. 즉, 1 만여 개 초·중·고등학교와 특수학교, 178 개 교육지원청, 16 개 시·도교육청 및 교육과학기술부가 
모든 교육행정 정보를 전자적으로 연계 처리하고, 국민의 편의를 증진시키기 위해 행정안전부 $(\mathrm{G} 4 \mathrm{C})$, 대법원 등 유관 기관의 행정정보를 이용할 수 있는 종합적인 대국민서비스 이다[3]

주요서비스로 학부모서비스와 학생서비스, 온라인대입전 형 및 교직원 온라인 채용, 검정고시 온라인접수, 홈에듀 민 원서비스, 사용자 지원서비스, 일반 행정정보를 제공한다. 그 중에서도 본 연구의 대상이 되는 학부모서비스는 학부모의 교육 참여를 통해 교육기본법 제 13 조에서 규정하는 교육할 책임과 권리를 다할 수 있도록 제공하는 서비스를 말한다. 즉, 학부모들은 학교를 직접 찾아가지 않아도 학교정보 및 교육통신은 물론 자녀의 성적, 출결, 학교생활기록부 등 자 녀와 관련된 학교생활 전반의 기록을 인터넷을 통하여 열람 할 수 있고, 상담을 통해 자녀의 담임선생님과 상호 의견을 교환할 수 있는 쌍방향 서비스이다. 학부모서비스는 학교정 보(9종), 학생정보(21종), 학부모상담관리(3종), 자녀교육활용 정보(6종), $\mathrm{PAPS}(14$ 종) 등 총 55종의 열람 및 활용 서비스 를 제공하고 있으며, 추후 방과후 학교 항목을 추가로 개설 할 예정이다.

NEIS 정보시스템은 기존 교육행정정보시스템의 문제점을 해결하고 각 학교별로 개별적으로 운영되던 정보시스템을 통합·운영하려는 목적을 갖고 있다. NEIS를 통한 선진 $\mathrm{e}^{-}$교 육행정정보서비스 제공을 비전으로 업무처리 방식의 개편을 통한 교원의 업무 경감과 자녀의 학교생활정보 제공을 통한 학교와 가정의 역할 제고, 국민을 위한 빠르고 편리한 민원 서비스 제공, 교육행정 업무의 효율적 처리와 투명성 제고, 대입전형자료의 전자적 One-Stop 서비스 제공으로 투명하 고 편리한 대학입시 지원, 국가 경쟁력 제고를 위한 지식정 보사회형 전자정부의 확립을 목표로 한다. 특히 2011년 3월 부터 적용된 차세대 NEIS 서비스는 기존의 NEIS를 한 단 계 개선한 교육행정정보시스템으로 교과 교실제, 입학사정 관제 등 새로운 교육정책을 반영하고, 방과후학교관리, 성적 및 통계처리 기능 제공 등 교원의 업무경감과 편의성 향상 에 중점을 두었다.

\section{3. 연구설계 및 조사}

NEIS 학부모서비스 활용시 영향을 미치는 범주 및 요소 들에 대한 $\mathrm{ANP}$ 분석을 실시하기 위한 네트워크를 설계하 고, 학부모를 대상으로 하는 설문계획과 이들에 대한 기초 정보를 정리하여 제공한다.

\section{1 네트워크의 구성}

본 연구는 문헌연구를 통해 대국민서비스를 지원하는 정 보시스템의 수용에 관한 특징을 기존 연구에서와 같이 $\mathrm{TAM}$ 모형을 적용할 수 있는 자율적 시스템이 아니면서도, $\mathrm{TPB}$ 혹은 $\mathrm{DTPB}$ 모형을 적용할 수 있는 강제적 시스템도 아닌 것으로 규정하였다. 이에 Dual Model에서와 같이 혜택 과 전환비용 사이의 관계를 따지는 방안을 제시하였다. 한
편 $\mathrm{ANP}$ 의 $\mathrm{BCR}$ 모델은 특정 의사결정 사안에 대해 혜택, 비용, 위험 등의 상호관계를 체계적으로 분석하는 방법론으 로, TAM, TPB, DTPB 모형에서의 유용성에는 $\mathrm{BCR}$ 모델 의 혜택과 기회가 해당되며, Dual Model에서의 전환비용에 는 $\mathrm{BCR}$ 모델의 비용과 위험이 해당된다. 이에 (그림 1)과 같이 $\mathrm{ANP}$ 의 $\mathrm{BCR}$ 모델을 분석하기 위한 네트워크를 구성 하였으며, 평가요소 간의 상관관계는 ANP Application Program인 'Super Decision'을 이용해 표현하고 분석하였다.

\subsection{1 혜택(Benefits)}

학부모들은 NEIS의 학부모서비스를 이용함으로써 내 자 녀의 성적, 건강상태 등과 같은 정보를 얻을 수 있으며, 교 육관련 제 증명을 발급받을 수도 있고, 또한 내 자녀에게 알맞도록 교육을 추진하기 위한 참여의 기회를 갖는 등 다 양한 혜택을 누릴 수 있게 된다.

이들 혜택을 자세히 살펴보면 먼저, 교육과학기술부는 $\mathrm{NEIS}$ 를 통하여 학부모들에게 학교 정보는 물론 내 자녀의 정보를 제공함으로써 학부모와 학교를 이어주는 온라인상의 통로를 마련하고 학부모들을 학교교육의 교육공동체로 거듭 날 수 있도록 돕고 있다[32]. NEIS를 통하여 제공되는 '내 자녀 바로알기' 학부모서비스는 학부모가 학교를 직접 찾아 가지 않아도 자녀의 교육과정과 성적, 일일출결사항, 학교생 활기록부(수상경력, 자격증, 체험학습활동), 건강기록부, 진로 상담 자료 등 학생정보를 열람할 수 있고, 학사일정, 교육통 신, 급식식단표 등 자녀의 학교생활 전반에 관련된 학교정 보를 열람할 수 있는 서비스이다. 더불어 학업지도, 인성지 도, 진학지도, 진로지도, 특수아지도 등의 교육정보를 열람할 수 있으며, 향후에는 방과후 학교 수강내역과 창의적 체험 활동, 대입전형자료 등의 서비스 항목도 증설할 계획이다. 또한 선생님과의 상담을 신청할 수 있고, 온라인상에서 직 접 상담이 이루어질 수도 있으며, 학교에서 제공되는 교육 통신 등을 확인할 수 있어 담임선생님과의 상호의견 교환이 가능한 쌍방향서비스를 제공한다.

NEIS는 홈에듀 민원서비스 메뉴를 통하여 교육관련 제증 명 민원을 인터넷상에서 직접 사용자의 $\mathrm{PC}$ 및 프린터를 이 용하여 발급받을 수 있는 온라인 민원서비스를 제공하고 있 다. 홈에듀 민원서비스에서는 교육행정 업무와 정보를 공동 활용함으로써 행정정보 유통촉진을 통한 교육행정의 생산성 과 투명성을 향상시키며, 교육행정기관이 보유한 행정정보 를 인터넷을 통하여 국민에게 제공함으로써 '국민의 알 권 리'를 충족시킴과 동시에 졸업증명서 등 연간 800 만 건에 이르는 교육행정 관련 각종 증명서를 전국의 모든 교육기관 에서 실시간 발급할 수 있도록 하여 원거리 이동으로 인한 국민의 불편함을 최소화하고, 민원서비스의 접근성을 향상 시키고 있다.

학부모는 또한 NEIS를 통하여 교육과정의 운영 등에 대 한 의견 개진 및 수업시간표에 따른 준비물을 미리 준비할 수도 있으며, NEIS에서 제공되는 급식식단표를 파악하여 자 녀의 음식 알레르기 등을 사전에 예방하고, 예방접종 관리, 신체검사 및 건강검진 결과 등을 토대로 건강을 개선할 수 


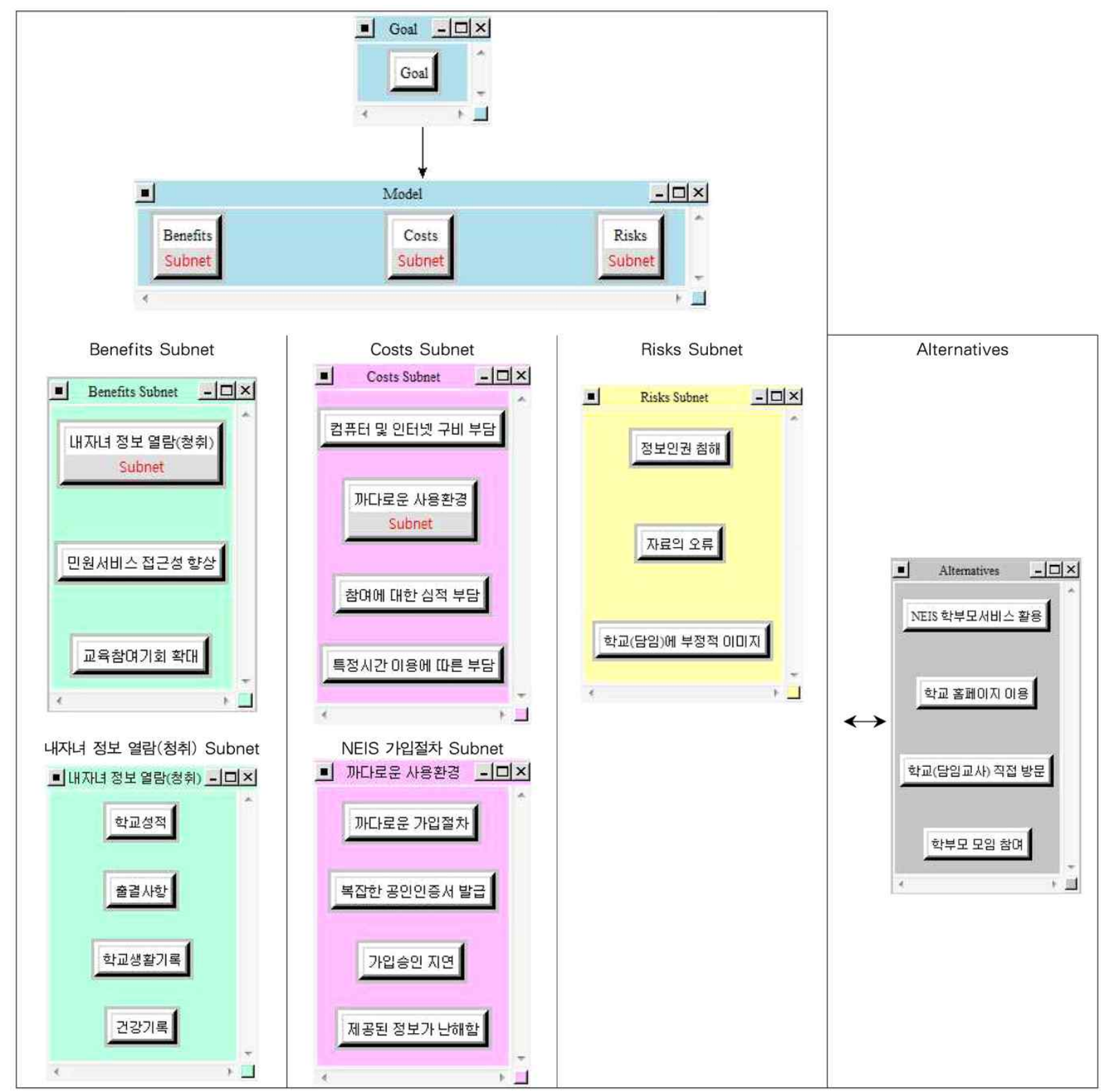

(그림 1) ANP 분석을 위한 네트워크 구성

있다. 또한 학생 정보 열람을 통하여 자녀의 교육지도는 물 론 자녀와 함께 학업성취도 향상 방법에 대한 대화를 나눌 수 있으며, 학습이 부족한 교과 및 학업성취도가 낮은 교과 에 대한 학습 태도 개선 방법 등에 대하여 자녀와 함께 대 책을 수립할 수 있어 올바른 자녀교육의 방향성을 추구하고, 나아가 학부모의 교육 참여의 기회를 확대할 수 있다. Sallis[33]는 학부모의 학교교육 참여의 효과성에 대하여 학 부모에게 선택권이 주어지면 학부모 개개인의 의사결정이 축적되어 학교가 교육의 질을 개선하게 하는 효과를 가져온 다고 설명하였다. 자녀를 교육함에 있어 학교와 가정이 공 동의 책임을 져야한다는 당위성에 비춰보더라도 학교교육은 가정과 단절되거나 분리해서 생각할 수 없는 불가분의 관계 이다[7].

\subsection{2 비용 (Costs)}

반면 학부모들이 NEIS의 학부모서비스를 통해 얻을 수 있는 혜택을 누리기 위해서는 돈, 시간, 심적 부담 및 노력 등과 같은 비용적인 측면이 발생할 수 있다.

예컨대, 학부모들이 온라인상에서 자녀의 정보를 열람하 기 위해서는 먼저 인터넷을 사용할 수 있는 환경이 마련되 어야 한다. 컴퓨터가 없는 경우에는 컴퓨터를 구입해야 하 고, 인터넷을 사용하기 위해 인터넷 회선도 증설해야 하는 등의 사전 준비가 필요하다. 그러나 인터넷 사용환경을 구 축했다 하더라도 중장년층 특히 전업주부의 경우 컴퓨터 및 인터넷 활용 교육에 대한 부담감이 발생할 수 있다. 또한 학부모서비스를 이용하기 위해서는 공인인증서를 신청·발급 받아 NEIS 사이트에 접속하여 회원가입을 하고, 학부모서비 
스를 신청한 후에는 학교로부터 승인을 허가받는 과정을 거 쳐야 한다. 승인이 완료되면 비로소 학부모들은 학부모서비 스를 통해 자녀의 정보와 학교 정보를 열람할 수 있게 된다 학부모서비스를 이용하기 위한 이러한 일련의 과정들은 정 보화 활용이 미흡한 학부모들에게 부담으로 작용될 수 있으 며, 가입 승인 지연 및 절차의 까다로움 역시 NEIS 가입 자 체의 부담으로 작용될 수 있다.

NEIS 서비스 내용 인지의 어려움 및 제공되는 정보 자체 의 어려움 역시 학부모들의 NEIS 사용을 저해하는 요인이 다. 예컨대, 현재 차세대 NEIS 사이트의 경우 학부모서비스 $\mathrm{Q} \& \mathrm{~A}$ 에 내용이 전혀 제공되고 있지 않는데, 정보 입력이 지 연되어 안 된 것인지, 아니면 제도상 원래 제공되지 않는 것인지 등에 대한 안내가 없다. 유정수와 백현기[7]는 NEIS 서비스를 통한 학부모의 학교교육 참여 촉진방안에 대하여 학교 홈페이지를 통한 NEIS 서비스 질의 및 응답 게시판을 운영하고 실시간 응답 체제를 구축하여 학부모들의 관심을 높이고 있다. 또한 NEIS 서비스 활용 콘텐츠 및 서비스 조 회항목을 다양화하여 학부모들이 보다 쉽고 편리하게 활용 할 수 있도록 시스템을 보완해야한다고 주장한 바 있다.

\subsection{3 위험(Risks)}

NEIS는 교육행정의 효율성 증진과 대국민 서비스의 질 향상, 그리고 교원의 업무 경감 등을 위해 도입되었지만, 도 입초기부터 여러 가지 문제점들이 지적되었다. 대표적인 문 제점으로 학생들의 개인 정보 공개에 대한 인권문제를 들 수 있으며[32], 학부모서비스를 통해 제공되는 자료의 오류 및 실시간 갱신의 문제 역시 학부모서비스 확산 및 활용에 걸림돌로 작용하는 문제로 대두되고 있다[2,4].

차세대 NEIS 서비스는 학생중심의 교육과정을 강화하는 차원에서 학생에게도 접근권을 허용하여 NEIS를 통해 본인 의 성적, 표준점수 분석표, 성적 변화표, 본인이 작성한 시험 답안, 학업성취도평가 결과, 개인별 맞춤형 학습정보, 학교생 활기록부, 체력검사 결과 등을 확인할 수 있다. 국가인권위 원회가 2008년 12 월 학생의 자기정보 열람을 제한하는 것은 인권침해소지가 있다며 개선을 권고한 적이 있는데, 이를 수용한 교육과학기술부는 학생중심의 교육과정 운영이 본격 화됨에 따라 학생들이 스스로 학습능력을 신장시킬 수 있도 록 지원을 강화하기 위해 이 시스템을 도입한다고 밝힌바 있다.

자료의 오류 및 시스템 접근 오류 역시 NEIS 확산 및 활 용을 가로막고 있다. 일례로 올해 초 학교에서는 교육통신 및 알림장, 학교홈페이지 게시판 등을 통하여 학부모서비스 가입을 종용하였지만, 정작 해당 사이트인 NEIS는 시스템 점검을 이유로 접근조차 불가능하여 가입이 안 되는 상황이 벌어지기도 했다. 또한, 학부모 입장에서는 학생 개인의 신 상은 물론 부모의 정보까지 일부 공개되다보니 보안문제에 대한 기우가 생기는 건 어떻게 보면 당연한 반응일 수밖에 없다.

\section{2 설문 대상자}

설문은 NEIS의 학부모서비스의 직접적인 이용대상자인 학부모들을 대상으로 이루어졌다. 설문 진행에는 현실적으 로 어려운 점이 있었다. 학부모들이 일반적인 설문지의 양 식에는 익숙해 있었으나 $\mathrm{ANP}$ 의 설문지에 대해서는 어떻게 답변해야 할지 어려움을 느끼고 있었다. 또한 40대 이후의 여성 학부모들은 설문 자체에 대한 이해도도 다소 떨어지는 것으로 판단되었다. 이에 연구자들은 소수 학부모와의 직접 적인 접촉을 통해 설문의 취지를 설명하고 일일이 문항 각 각에 대한 설명을 해주는 것이 불가피해졌다. 이에 저자 중 에서 서울 소재의 $\mathrm{S}$ 초등학교 2 학년의 자녀를 두고 있는 연 구자가 학교의 2 학년 3 개 반, 3 학년 2 개 반의 학부모 모임에 접촉하여 설문을 의뢰하였으며 설문에 응해준 학부모에 대 해서는 소정의 기념품을 증정하였다. 학부모 소수 모임에 대한 참여와 설문이 이루어졌기 때문에 2011년 6, 7월, 2개 월에 걸친 설문이 이루어졌음에도 전체 63부의 설문지를 수 거하는 데 그쳤다. 그러나 전문가(본 연구에서는 NEIS 학부 모서비스의 이해당사자인 학부모)의 견해가 반영되는 경우 설문부수에는 큰 영향이 없을 것으로 판단되어 본 연구의 분석에 이용하였다. 설문대상자의 현황은 <표 $1>$ 과 같이 정 리하여 제시하였다.

〈표 1〉 설문대상 현황

\begin{tabular}{|c|c|c|c|c|c|c|c|}
\hline & \multirow{2}{*}{ 구 분 } & \multicolumn{4}{|c|}{ NEIS 이용여부 } & \multicolumn{2}{|c|}{ 학부모 } \\
\hline & & 이용 & $\%$ & 비이용 & $\%$ & 계 & $\%$ \\
\hline \multirow{2}{*}{ 성별 } & 남성 & 1 & 3.7 & 2 & 5.6 & 3 & 4.8 \\
\hline & 여성 & 26 & 96.3 & 34 & 94.4 & 60 & 95.2 \\
\hline \multirow{5}{*}{ 나이 } & 30대 초반 & 2 & 7.4 & 4 & 11.1 & 6 & 9.5 \\
\hline & 30대 후반 & 13 & 48.1 & 16 & 44.4 & 29 & 46.0 \\
\hline & 40대 초반 & 11 & 40.7 & 13 & 36.1 & 24 & 38.1 \\
\hline & 40대 후반 & - & - & 3 & 8.3 & 3 & 4.8 \\
\hline & 50대 초반 & 1 & 3.7 & - & - & 1 & 1.6 \\
\hline \multirow{2}{*}{$\begin{array}{l}\text { 자녀 } \\
\text { 학년 }\end{array}$} & 2학년 & 22 & 81.5 & 24 & 66.7 & 46 & 73.0 \\
\hline & 3학년 & 5 & 18.5 & 12 & 33.3 & 17 & 27.0 \\
\hline \multirow{2}{*}{$\begin{array}{l}\text { 인지 } \\
\text { 여부 }\end{array}$} & 인지 & - & - & 25 & 69.4 & - & - \\
\hline & 비인지 & - & - & 11 & 30.6 & - & - \\
\hline \multicolumn{2}{|r|}{ 계 } & 27 & 42.9 & 36 & 57.1 & 63 & 100 \\
\hline
\end{tabular}

분석 과정에는 NEIS 학부모서비스를 이용하고 있는 그룹 (42.9\%)과 이용하지 않는 그룹(57.1\%)으로 나누어 분석을 함으로써 NEIS의 학부모서비스를 활성화하기 위한 시사점 을 찾고자 노력하였다. 이용자 여부에 상관없이 남성이 3 명 (4.8\%)에 불과했고, 나이는 30대 후반(46.0\%)과 40대 초반 (38.1\%)이 가장 많은 분포를 보였다. 설문대상자의 최장년자 는 51세(1명)였으며, 최연소자는 33세(2명)였다. 자녀의 학년 은 2학년이 46명(73.0\%)으로 가장 많았다. NEIS 학부모서비 스를 이용하지 않고 있는 경우에는 해당 서비스가 제공되고 있는 것을 알고 있었는지 여부를 묻는 설문을 하였다. 비이 용자 36명중 NEIS의 학부모서비스를 알고 있었다고 답변한 
〈표 2〉 NEIS 학부모서비스 이용자 그룹별 BCR 및 대안 선호도 우선순위 비교

\begin{tabular}{|c|c|c|c|c|c|c|}
\hline & \multicolumn{2}{|c|}{$\mathrm{BCR}$ 우선순위 } & \multicolumn{4}{|c|}{ 대안 우선순위 } \\
\hline \multirow{5}{*}{ 이용자 } & \multirow[b]{2}{*}{ Benefits } & \multirow[b]{2}{*}{0.52819} & Name & \multirow[t]{2}{*}{ Graphic } & Ideals & Normals \\
\hline & & & NEIS 학부모서비스 활용 & & -0.081805 & -0.050566 \\
\hline & Costs & 0.13379 & 학교 홈페이지 이용 & & 1.000000 & 0.618126 \\
\hline & \multirow[t]{2}{*}{ Risks } & \multirow[t]{2}{*}{0.33802} & 학교(담임) 직접 방문 & & -0.465384 & -0.287666 \\
\hline & & & 학부모 모임 참여 & & -0.070603 & -0.043642 \\
\hline \multirow{5}{*}{ 비이용자 } & \multirow{2}{*}{ Benefits } & \multirow{2}{*}{0.52360} & Name & \multirow[t]{2}{*}{ Graphic } & Ideals & Normals \\
\hline & & & NEIS 학부모서비스 활용 & & -0.107821 & -0.075294 \\
\hline & Costs & 0.15172 & 학교 홈펭이지 이용 & & 1.000000 & 0.698331 \\
\hline & \multirow[t]{2}{*}{ Risks } & \multirow[t]{2}{*}{0.32468} & 학교(담임) 직접 방문 & & -0.268103 & -0.187224 \\
\hline & & & 학부모 모임 참여 & & -0.056063 & -0.039150 \\
\hline
\end{tabular}

사람은 25 명으로 $69.4 \%$ 였으며, 전혀 몰랐다고 응답한 학부 모도 $30.6 \%$ 에 이르는 등 해당 서비스의 홍보가 부족했던 것 으로 판단된다.

\section{ANP 분석결과}

본 장에서는 $\mathrm{ANP}$ 의 분석결과를 제시하되, 본 연구의 시 사점을 효과적으로 도출하기 위해 NEIS 학부모서비스의 이 용자와 비이용자 그룹으로 나누어 분석결과를 제시한다.

\subsection{BCR 우선순위 결과}

NEIS 학부모서비스의 이용자 및 비이용자의 각 선호도에 대한 가중치를 결정하기 위하여, 본 연구에서 구성한 네트 워크에 따른 설문에 대해 쌍대비교를 실시하였다. 또한 개 별 설문 문항 중 일관성 비율(CR값)이 0.1 이상인 항목은 일관성이 없는 것으로 판단하지만(Saaty, 2003), 본 연구에 서는 모두 0.1 이하인 것으로 분석됨으로써 타당성이 확보 되었다.

$\mathrm{ANP}$ 분석 결과, NEIS 학부모서비스의 이용 여부에 따른 혜택, 비용, 위험에 대한 고려 정도와 학부모서비스를 포함 한 대안의 선호도에 대한 우선순위 정도를 <표 2>와 같이 도식화하였다. 결론적으로 학교 및 담임교사를 찾는 것에 대한 부정적 인식 정도를 제외하고는 모두 비슷한 양상을 보이고 있었다. 조금 더 살펴보면, 학부모서비스 이용 여부 에 상관없이 학부모로써 어떠한 혜택을 받게 될지에 대해 관심이 가장 높았으며(이용자: 0.528, 비이용자: 0.524; $\mathrm{ANP}$ 가중치 결과), 혜택을 받기 위해 감수해야 하는 위험에 대한 고려 정도가 두 번째로 높았다(이용자: 0.338 , 비이용자: 0.325). 또한 비용에 대한 고려 정도는 모두 가장 낮은 것으 로 나타났다(이용자: 0.134, 비이용자: 0.152). 이러한 $\mathrm{BCR}$, 즉, 혜택, 비용, 위험 등에 대한 고려 정도를 종합한 대안에 대한 우선순위(Synthesized Priorities)를 살펴보면, 학부모서 비스 이용 여부와 상관없이 학교 홈페이지 이용을 가장 선 호하는 것으로 나타났으며(이용자: 0.618, 비이용자: 0.698), 그 외 대안들에 대해서는 다소 부정적인 것으로 나타났다.
다만 이용자 그룹은 학교 혹은 담임교사 방문을 가장 부담 스럽게 여기는 것으로 나타났다(이용자: -0.288 , 비이용자 -0.187). 본 연구에서 관심이 높았던 NEIS 학부모서비스는 이용 여부에 상관없이 다소 낮은 우선순위(이용자: -0.05 , 비 이용자: -0.08)를 보이고는 있으나 그 가중치 정도가 매우 낮아 학부모들의 NEIS 서비스에 대한 태도는 긍정 혹은 부 정적 태도를 가지고 있다고는 말하기에는 어렵다. 이를 알 아보기 위해서는 $\mathrm{BCR}$ 각각 및 그 대안에 대한 우선순위 고 려 정도를 살펴볼 필요가 있다.

\subsection{1 혜택에 따른 대안 선호도 결과}

NEIS 학부모서비스의 이용자 및 비이용자들이 선호하는 혜택은 무엇이며, 또한 그에 따라 선호하는 대안은 <표 3> 과 같이 도식화하여 정리하였다. 이들 내용을 살펴보면 먼 저, 학부모들이 원하는 대안은 많은 사람들이 예상할 수 있 는 바와 같이 내 자녀 정보를 얻는 것이 가장 컸다(이용자 0.625, 비이용자: 0.628). 내 자녀를 위해 교육에 참여하는 기 회로 생각하는 것이 두 번째였으며(이용자: 0.278 , 비이용자: 0.257), 제 증명 등과 같이 민원서비스에 대한 접근성 향상 은 가장 관심도가 낮았다(이용자: 0.097, 비이용자: 0.115). 학부모들이 생각하는 혜택 정도에 따른 대안 선택은 학교 홈페이지 이용을 가장 선호하고 있는 것으로 나타났다(이용 자: 0.387, 비이용자: 0.413). 현재 NEIS의 학부모서비스를 이용하고 있는 그룹도 해당 서비스에 대한 선호도는 가장 낮은 것으로 나타났다(이용자: 0.189; 비이용자: 0.179). 선택 가능한 대안 중 학교를 직접 방문하는데 따른 불편과 제한 된 정보를 얻게 되는 학부모 모임 참여보다 NEIS 혹은 학 교 홈페이지에 대한 선호도가 있을 것으로 예상하였으나 학 교 홈페이지에 대한 선호도는 압도적인 반면, NEIS에 대한 선호도는 가장 떨어졌다. 이는 현재 NEIS가 제공하고 있는 정보에 대해 만족스러운 혜택을 학부모들이 느끼지 못하고 있는 것으로 판단된다.

또한 학부모들이 가장 큰 관심을 보였던 내 자녀의 정보 에 대한 선호도를 살펴보면 NEIS의 학부모서비스를 이용자 와 비이용자 간에 차이를 보였다. 비이용자들은 내 자녀의 
〈표 3〉NEIS 학부모서비스 이용 여부에 따른 Benefits 및 선호 대안 비꾜

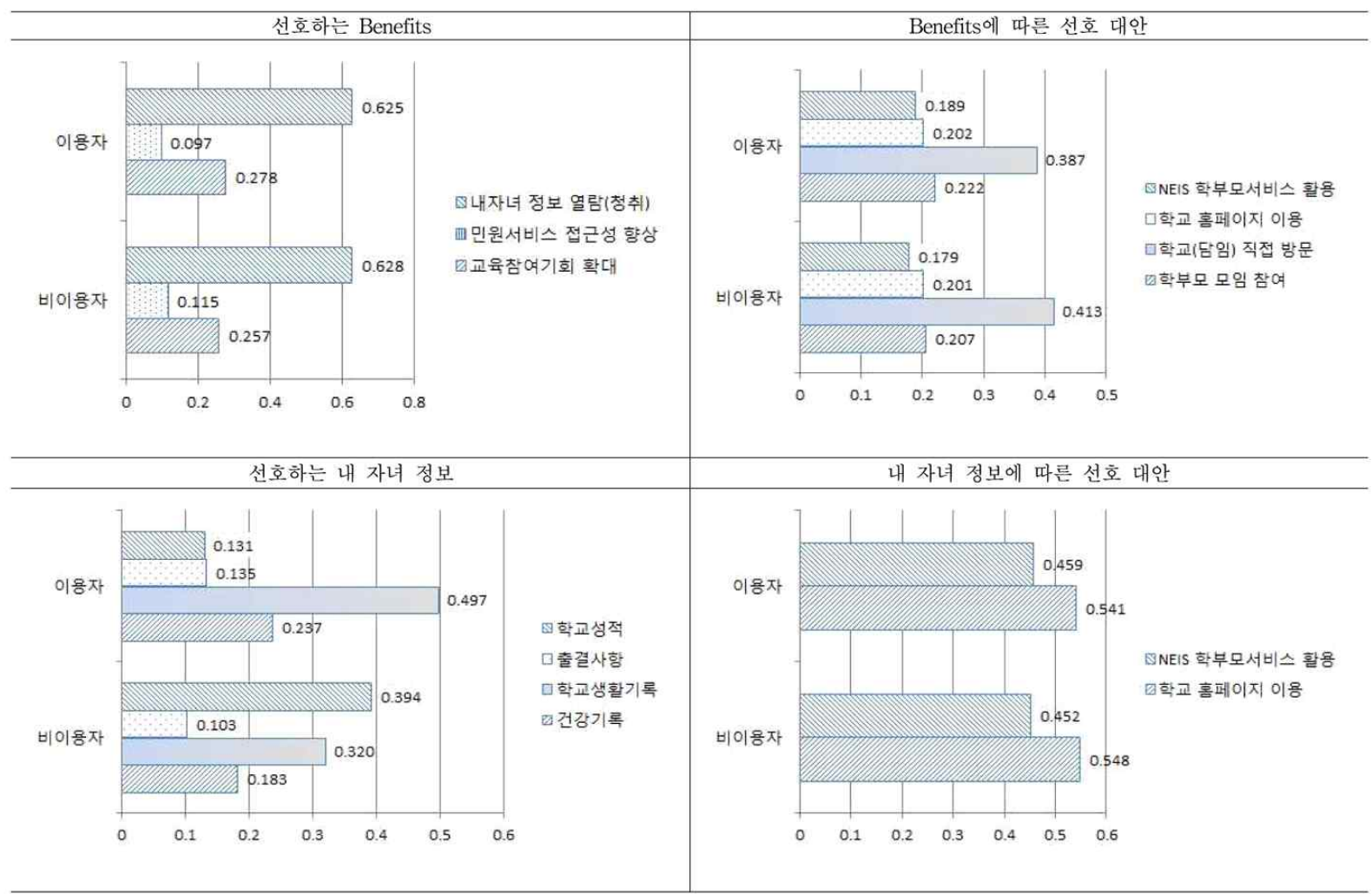

학교성적에 대해 가장 큰 관심을 보인데(0.394) 반해, 이용 자들은 가장 낮은 가중치를 보였다(0.131). 본 연구는 초등 학교 학부모들을 대상으로 설문을 진행하였으나 내 자녀가 어릴 때부터라도 학교 성적에 대해 최우선적으로 큰 관심을 보인데 반해, 실제로는 학교 성적이 제공되고 있지 않음에 따라 이용자 그룹은 가장 낮은 만족도를 보이고 있었다. 현 실적으로 NEIS 학부모서비스를 활성화하기 위해서는 해당 정보의 제공이 가장 큰 기여를 할 것으로 보인다. 그 외 내 자녀 정보에 대해서는 가중치 구성도는 다르지만 동일한 우 선순위를 보이고 있다. 즉, 학교생활기록(이용자: 0.497, 비이 용자: 0.320), 건강기록(이용자: 0.237, 비이용자: 0.183), 출결 사항(이용자: 0.135, 비이용자: 0.103) 순의 선호도를 보였다. 내 자녀의 학교 출결사항은 이상이 있는 경우 학교 선생님 들이 통지문 혹은 연락을 해오기 때문에 자연스럽게 접할 수 있는 정보이므로 가장 낮은 선호도를 보인 것으로 판단 된다. NEIS 이용자 그룹은 학교생활기록에 대해 가장 만족 하고 있는 것으로 나타났다. 내 자녀의 정보를 열람하기 위 해 선호하는 대안에 대해서는 학교 홈페이지(이용자: 0.541, 비이용자: 0.548)에 대한 선호도가 $\mathrm{NEIS(이용자:} \mathrm{0.459,} \mathrm{비이}$ 용자: 0.452)에 비해 앞선 것으로 나타났다. 결국 NEIS 학부 모서비스를 통한 교육참여 기회가 적거나 부담스럽고, 민원 서비스에 대한 접근성이 제한적이기 때문이며 전반적으로 좋지 못한 선호도를 보인 것은 Costs나 Risks에 대한 부담 이 있는 것으로 판단되는 바, 이에 대한 분석도 요구된다.
4.1 .2 비용(Costs) 부담에 따른 대안에 대한 평가

NEIS 학부모서비스 이용자 및 비이용자들이 부담스러워 하는 비용에 대해 살펴보면(<표 $4>$ 참조), 두 그룹 모두 비 슷한 양상을 보이고 있었으며, 이들 대안들에 대해 참여하 거나 이해관계자들과의 관계를 가장 어려워하는 것으로 나 타났다(이용자: 0.656, 비이용자: 0.547). 다음으로는 특정시 간 이용에 따른 부담으로(이용자: 0.198, 비이용자: 0.243) 학 교 또는 담임교사 방문과 학부모 모임 참여에 해당되는 내 용이며 이로 인해 NEIS 혹은 학교 홈페이지를 이용하는 것 으로 풀이된다. 설문을 진행하는 과정에서 응답자들은 컴퓨 터 및 인터넷 구비 부담은 거의 못느낀다는 의견을 피력했 다. 따로 설문은 시행하지 않았지만 이미 많은 가정에서는 인터넷 설치는 기본이며 컴퓨터 또한 집집마다 컴퓨터를 사 용하고 있는 것으로 나타났기 때문이다. 본 연구에서는 기 존 연구들을 참조하여 NEIS 가입절차 등 까다로운 사용환 경이 학부모서비스의 활성화에 걸림돌로 작용할 것으로 예 상하였으나, 기존 인터넷 사용환경에 적응한 학부모들은 그 리 큰 문제점으로 작용하지 않는 것으로 나타났다(이용자: 0.103 , 비이용자: 0.243). 이들 비용에 대한 부담으로 인해 학 부모들은 학교를 찾아가거나 담임교사와의 직접적인 대면을 가장 부담스러워 하는 것으로 나타났다. 종합하면 정보통신 에 대한 사용환경 보다는 한국적인 교육환경으로 인해 학교 및 담임교사, 타 학부모와의 관계모임에 참여하는 문화적인 문제를 가장 부담스러워 한 것으로 나타났다. 따라서 NEIS 
〈표 4〉NEIS 학부모서비스 이용 여부에 따른 Costs 부담 및 대안의 구성 비교

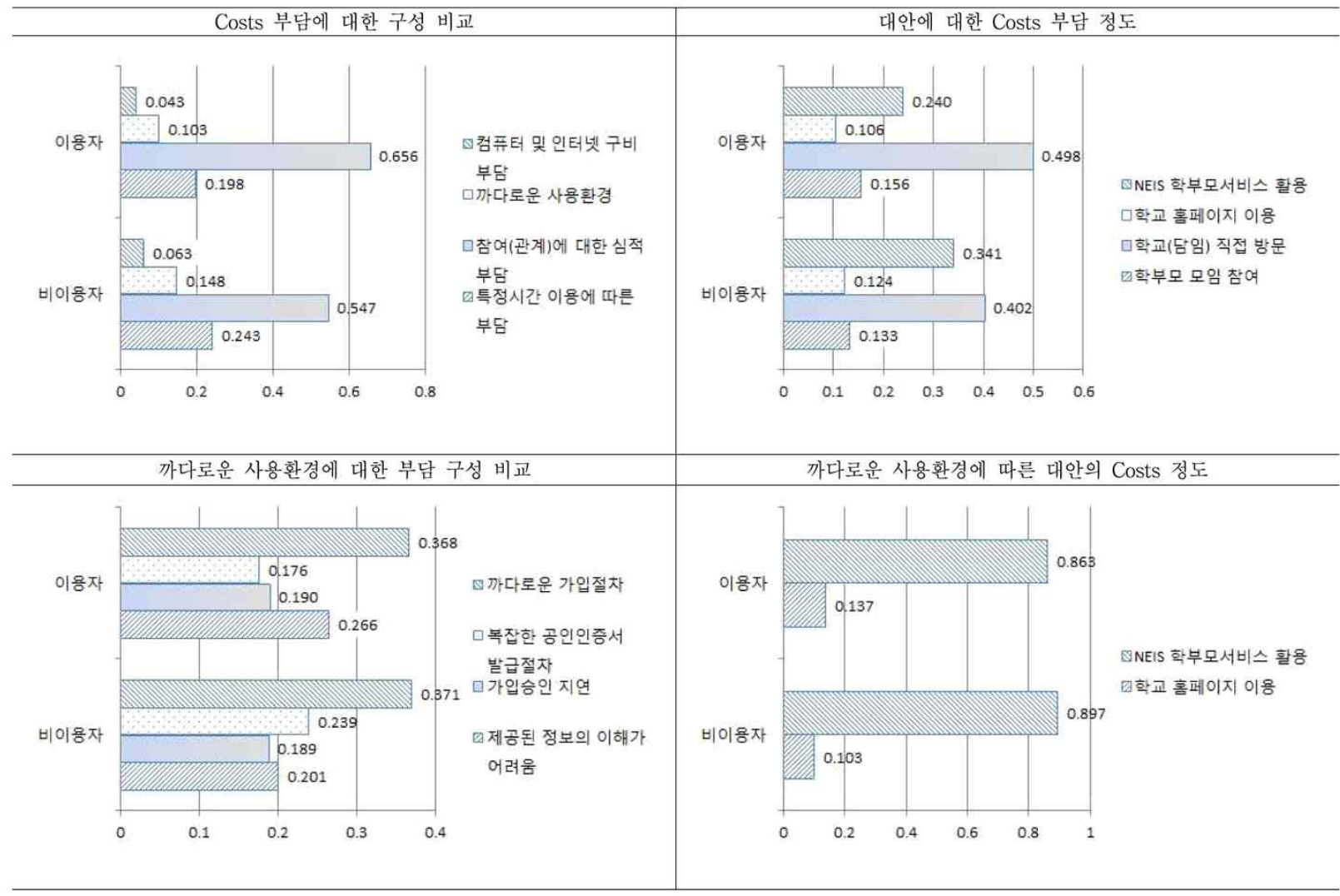

학부모서비스와 학교 홈페이지는 이러한 관계에 따라 대안 이 될 수 있겠지만, 학부모들은 학교 홈페이지에 대해서는 부담이 없었으나(이용자: 0.106, 비이용자: 0.124), NEIS의 서 비스에 대해서는 두 번째로 큰 부담으로 느끼고 있었다(이 용자: 0.240, 비이용자: 0.341). 특히 이용자들은 비이용자들 에 비해 그 부담 정도가 많이 경감하는 것으로 볼 때(사용 전에 비해 부담이 완화되기 때문에), NEIS의 학부모서비스 에 대한 홍보가 보다 쉽게 이루어짐으로써 학부모들이 기존 인터넷을 이용하듯이 쉽게 접근할 수 있어야 한다.

NEIS 학부모서비스 이용을 위한 사용환경적 부담으로는 이용자와 비이용자 모두 까다로운 가입절차를 들고 있었다 (이용자: 0.368, 비이용자: 0.371). 교육과학기술부가 운영하 는 NEIS 홈페이지에서 회원가입을 통해 로그인을 한 후 내 자녀의 학교와 자녀검색을 하고 서비스 승인 요청까지의 전 반적인 과정에 대해 부담을 느끼고 있었다. 그 다음으로 공 인인증서의 발급에 대해 비이용자(0.239)가 부담을 느끼고 있었으나 이용자들은(0.176) 가장 낮게 부담을 느끼고 있었 다. 실제 이용자들은 기존 온라인 거래의 경험과 다르지 않 기 때문에 큰 불편함을 느끼지 못하였다고 의견을 밝힌 반 면, 비이용자들은 막연한 부담으로 작용하였다. 따라서 $\mathrm{NEIS}$ 의 가입절차 홍보시 기존 인터넷 뱅킹과 동일한 공인 인증서 발급절차에 대한 문구를 사용하는 것이 필요하다. 가입승인 지연에 대해서는 이용자(0.190) 및 비이용자(0.189)
모두 비슷한 의견을 보였으나, 이용자들은 NEIS 홈페이지에 서 제공되는 정보의 이해가 어려운 것으로 나타났다. 예컨 대, NEIS를 통해 제공되는 초등학생의 성적에 대해 실제 학 교에서 교부하여 학부모들이 받아보는 성적표와 그 내용이 다르다. 어느 성적이 공식적으로 자녀의 성적을 대표하는지 그 내용을 분간하기 어렵다는 점에 대해 학부모들은 가장 많은 예를 들고 있었다. 결과적으로 학부모들은 시간 및 금 전, 심리적 부담에 대해 NEIS의 학부모서비스가 가장 큰 것 으로(이용자: 0.863, 비이용자: 0.897) 지적하였다.

\section{1 .3 위험(Risks) 부담에 따른 대안에 대한 평가}

NEIS의 학부모서비스 이용자 및 비이용자들이 우려하고 있는 위험에 대해 살펴보면(<표 5> 참조), 두 그룹 모두 비 슷한 양상을 보이고 있었다. 그 내용을 살펴보면 학부모들 은 학교 및 담임교사에게 부정적 이미지를 보임으로써(이용 자: 0.427, 비이용자: 0.463) 혹여 있을 자녀의 불이익을 가장 먼저 우려하는 것으로 나타났다. 기존 연구를 통해 예컨대, 내 자녀의 정보가 유출되거나 오류가 발생함으로 인해 사회 적으로 불이익을 받는 것보다도 더욱 크게 우려하고 있음을 알 수 있었다. 예컨대, NEIS에서 학교 교육과 관련하여 개 선되었으면 하는 내용을 올리고자 하여도, 해당 교육청에서 그 내용이 논의가 되고 해당 학교 및 담임교사에게 영향을 끼칠 수 있다는 것 자체만으로도, 내 자녀에게 불이익을 줄 
〈표 5〉NEIS 학부모서비스 이용 여부에 따른 Risks 부담 및 대안의 구성 비교

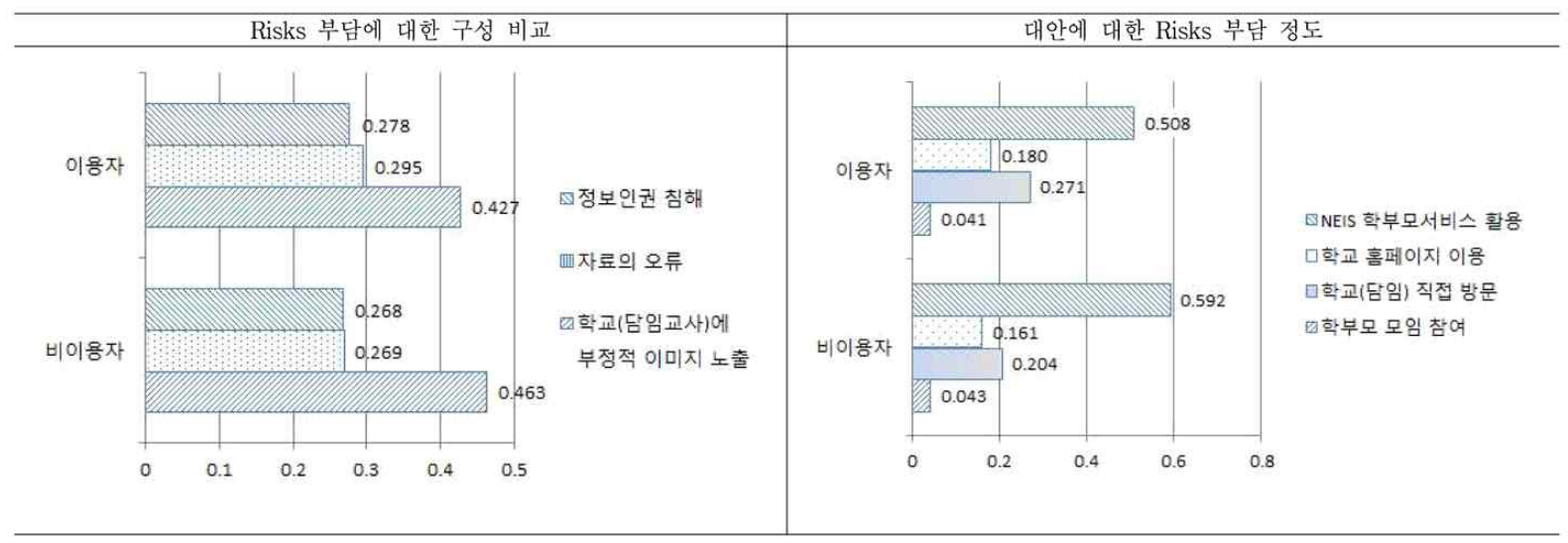

수 있다는 가능성으로 인해 NEIS 학부모서비스 이용이 제 한적일 수밖에 없다. 이용 여부와 상관없이 정보인권 침해 (이용자: 0.278, 비이용자: 0.268)와 자료의 오류(이용자: 0.295, 비이용자: 0.265)는 비슷한 수준에서 우려하는 것으로 나타났다.

위험 부담에 따른 대안에 대한 평가내용을 살펴보면, 학 부모들은 NEIS 학부모서비스에 대해 가장 크게 우려하는 것으로 나타났다(이용자: 0.508, 비이용자: 0.592). 학교 및 담임교사를 직접 방문하는 것은 두 번째로 우려하는 내용이 었다(이용자: 0.271, 비이용자: 0.204). 또한 정보인권 침해 및 자료의 오류에 대한 부담이 있어서인지 이전 분석에서의 혜택, 비용에 비해 학교 홈페이지 또한 다소 우려스러운 대 안인 것으로 평가되었다(이용자: 0.180, 비이용자: 0.161), 학 부모 모임 참여에 대해서는 이해관계가 가장 적어서인지 가 장 위험 부담이 적은 것으로 나타났다(이용자: 0.041, 비이용 자: 0.043).

\section{2 민감도 분석}

민감도 분석(Sensitivity Analysis)이란 평가기준이 되는 독립변수를 변화시킴에 따라 평가대안이 되는 Alternatives 의 우선순위의 변동을 관찰하는 분석이다[13]. 본 연구에서 는 학부모서비스를 통해 얻게 되는 혜택, 비용, 위험의 정도 에 따라 Alternatives인 NEIS, 학교 홈페이지, 학교(담임) 직 접 방문, 학부모 모임 참여 등 네 가지에 대한 선호도 변화 를 살펴보고자 하며, 이들 결과를 도식화하여 <표 6>과 같 이 제시하였다.

민감도 분석결과, 전반적으로는 NEIS 학부모서비스를 이 용하는 그룹과 그렇지 않은 그룹 사이에는 뚜렷한 차이를 보이고 있지 않은 것으로 나타났다. 이용자가 NEIS 활용 이 후 느끼는 변화가 뚜렷이 나타나지 않았을 가능성이 크다. 먼저 혜택에 대한 민감도에서는 전반적으로 학교 홈페이지 를 선호하고 있었으며, 이용자 또한 오히려 NEIS 보다도 학 교 홈페이지를 선호하고 있었다. NEIS의 경우에는 혜택에 대한 민감도가 0.5 정도(이용자: 0.54, 비이용자: 0.55; 민감 도) 이상인 경우에야 선호도가 정(+)인 것을 보이고 있으며,
그 이상 혜택이 커지는 경우에야 선호도가 급증하는 것으로 나타났다. 그러나 혜택의 민감도가 1 이 되어도 학교 홈페이 지를 앞지르지 못하는 것으로 나타났다.

학부모서비스의 내용에 따른 혜택을 얻기 위해 부담해야 하는 금전, 시간, 심리적 비용에 따라서는 NEIS의 경우 비 용에 대한 민감도가 예민한 것으로 나타났다. 비용에 대한 민감도가 0.1 정도만 되어도(이용자: 0.09, 비이용자: 0.10) $\mathrm{NEIS}$ 에 대한 선호도가 부정적으로 변하는 것을 확인할 수 가 있다. 그에 반해 학교 홈페이지는 비용에 대한 민감도가 둔하여 이용자인 경우 0.7 정도, 비이용자인 경우 0.8 정도 이내에서는 지속적으로 학교 홈페이지를 선호하고 있는 것 으로 나타났다.

위험 측면에서 NEIS는 비용 측면보다 다소 둔화되기는 하였어도 학교 홈페이지에 비해 더욱 민감한 것으로 나타났 다(이용자: 0.31, 비이용자: 0.29). 비용 측면과 마찬가지로 위험 정도에 따라 NEIS에 대한 선호도는 급감하는 것으로 나타났으며 전반적으로 학교 홈페이지에 대한 선호도가 0.7 정도 이내에서는 지속되는 것으로 나타났다.

$\mathrm{BCR}$ 전반적으로 보았을 때, 학부모들은 학교 홈페이지를 가장 선호하는 대안으로 보고 있었으며, NEIS는 민감도가 예민한 것으로 나타났다. 또한 학교 및 담임교사 방문은 선 호도에서 다소 부정적인 모습을 보였으며, 학부모 모임은 긍정적이지도 부정적이지도 않은 모습을 보이는 것으로 분 석되었다.

\section{5. 결론 및 시사점}

본 연구는 학부모서비스의 정보 수혜자에 대한 직접 설문 을 통해 NEIS 학부모서비스에 대한 명확한 인식수준을 알 고자 하였다. 더욱이 $\mathrm{ANP}$ 분석 결과를 토대로 NEIS에서 제공하는 학부모서비스의 혜택, 비용, 위험 등의 수준과 내 용을 고려하여 학부모들이 해당 서비스를 수용 혹은 다른 대안을 선호하는지 확인함으로써 활성화가 미흡한 분야를 보완하기 위한 전략적 방안을 마련할 수 있는 방향성 제시 가 가능해진다. 문창배 등[34]은 학부모서비스가 제공하는 
〈표 6〉 BCR에 따른 각 대안의 선택에 대한 민감도 분석

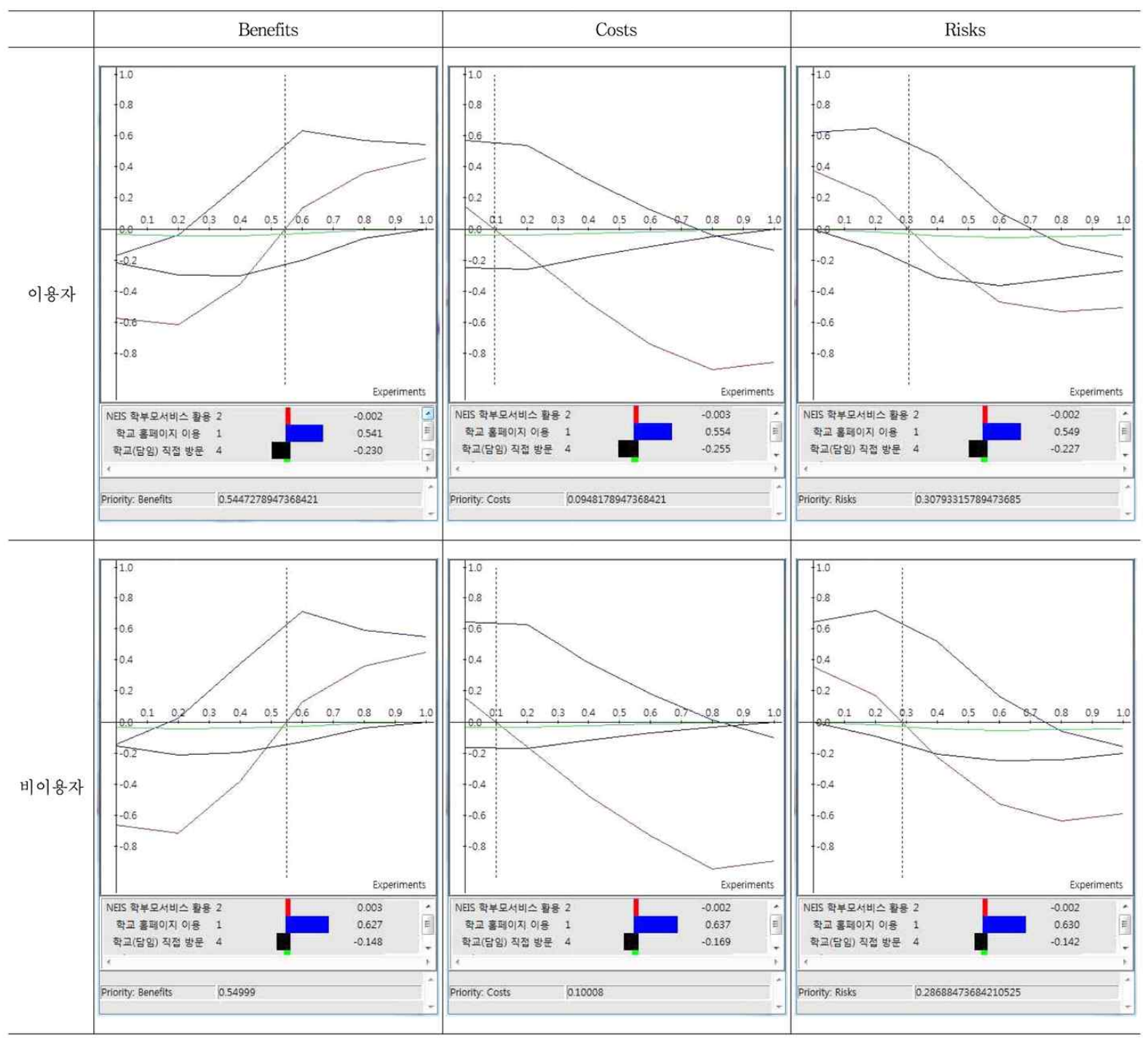

정보가 불충분하여 활성화가 미흡함을 지적한 바 있다. 본 연구에서는 학부모들이 제공받게 되는 교육관련 정보를 주 요 혜택으로 설정하였다. 그러나 이들 정보에 의한 혜택이 있음에도 불구하고 NEIS 학부모서비스 이용자들까지도 해 당 서비스가 아닌 학교 홈페이지 이용을 선호하고 있는 것 으로 나타났다. 또한 비용이나 위험 범주까지 고려했을 때 도 낮은 우선순위를 벗어나지 못하는 것으로 분석됨에 따라 NEIS 학부모서비스가 제공하는 정보의 수준과 내용이 변화 될 필요가 있다. 예컨대, 본 연구의 결과 NEIS 이용 여부에 상관없이 학부모들은 어느 정도 비용이나 위험을 감수하고 서라도 내 자녀의 정보를 얻는 것을 가장 선호하고 있는 것 으로 분석되었다. 현재 NEIS가 제공하는 정보의 정도가 비 이용자들의 기대치를 높일 수 있도록 자녀에 대한 보다 풍 부한 정보를 제공하되 최근 학부모들이 우려하고 있는 대규 모 성적정정사태와 같이 자료의 오류가 없는 정확한 정보가 제공될 필요가 있다.
한편 학부모들이 인지하는 혜택을 학부모서비스의 대안이 나 비용 혹은 위험 범주에 비해 우선시 함에도 불구하고 잘 몰라서 혹은 꺼려서 사용하지 않았다고 한다면 대국민서비 스 홍보에 부족함이 있게 된다. $\mathrm{ANP}$ 분석결과를 바탕으로 볼 때, NEIS 학부모서비스 이용자와 비이용자 간에 선호하 는 혜택의 내용은 전반적으로 차이가 없었다. NEIS에서 그 러한 혜택을 제공하고 있음을 알고 있었던 학부모는 비이용 자 중에서 $69.4 \%$ 를 차지하였으며, 그러한 정보를 원함에도 불구하고 해당서비스를 알지 못한 학부모가 $30.6 \%$ 에 해당되 었다. 따라서 $\mathrm{BCR}$ 전반에 걸쳐 이용 여부에 상관없이 비슷 한 양상을 보임에도 불구하고 NEIS 학부모서비스가 아닌 다른 대안을 공통적으로 선호하고 있는 것은 결국 학부모들 이 해당 서비스를 원함에도 불구하고 해당 서비스가 제대로 기능하지 못하고 있는 것으로 풀이된다. 지금까지 NEIS 학 부모서비스를 통해 제공되는 정보에 대해서도 학부모 자신 들이 분명한 혜택을 느끼지 못하는 것은 정보의 소비자인 
학부모들이 원하는 서비스를 제대로 제공하지 못하고 있기 때문이다.

또한 문헌고찰을 통해 정보시스템 사용환경, 까다로운 가 입절차 등이 큰 문제점으로 지적된 바 있다. 예컨대, 김수구 [32]는 NEIS의 학부모서비스에서 신청·승인 절차상의 문제 점, 학교와 교사에게 양질의 학부모서비스를 요청하지 못하 는 상황 등 때문에 학부모의 인식이 부정적으로 변화하고 있음을 밝힌 바 있다. ANP 분석을 통해 학부모서비스의 신 청·승인 절차에 필요한 시간 및 비용의 불편 감수가 정보인 권 침해와 같은 위험 범주와 자녀의 교육관련 정보의 혜택 범주에 비해 어느 정도 우선순위를 가지는지 확인할 수 있 게 된다. 필요한 경우에는 번거로운 신청·승인 절차를 획기 적으로 줄일 수 있는 방안에 대해 다시 논의할 필요가 있게 된다. 그뿐만 아니라 본 연구에서 제안하는 $\mathrm{BCR}$ 프레임워 크에 따라 NEIS 학부모서비스 가입절차가 혜택에 비해 까 다로운지 알 수 있게 되고 공인인증서 등 어느 부분에 대해 학부모들이 가장 어려워하는지도 알 수 있게 됨으로써 교육 에 대한 정책적 개선을 이끌 수 있게 된다. 그러나 본 연구 의 분석결과를 살펴보면 까다로운 가입절차나 정보시스템 사용환경보다도 교사와의 직접대면, NEIS에서의 교육참여가 자녀에 대한 불이익으로 작용할 가능성에 대해 우려하고 있 는 것과 같이 우리나라의 교육환경 실태를 반영하는 문화적 현실을 더욱 중요시 여김을 알 수가 있었다. 즉 까다로운 가입절차나 정보시스템 사용환경이 복잡해서 NEIS를 사용 하지 않는 것이 아님에도 정부는 전자정부의 효율성을 위해 사용자의 편의성에 중점을 두고 있었다. 이는 기존 TAM과 같이 기술수용 여부에 집중하는 연구의 단점이 되는 예가 된다. 따라서 본 연구에서와 같이 NEIS 학부모서비스를 $\mathrm{BCR}$ 프레임워크는 연구의 현실성을 강조하게 된다.

혹은 해당 서비스를 학부모들이 원하는 대안 매체로 변경 하는 것도 고려해볼 필요가 있다. 본 연구의 분석결과에 있 어서 전반적으로 학부모들은 NEIS의 학부모서비스 이용 여 부에 상관없이 가장 선호하는 대안은 학교 홈페이지를 이용 하는 것으로 나타났다. 설문대상의 자녀가 다니고 있는 초 등학교에서는 현재 학교홈페이지 및 학급 미니홈피를 제공 하고 있으며 방과후 과제, 기본적인 교육관련 안내사항, 학 급 현황 및 교사 소개, 시간표, 자녀 학급활동 사진 등과 같 은 자녀의 기본적인 정보를 제공하고 있다. 학부모들로부터 설문을 받으면서 인터뷰하는 과정에서 학부모들은 접근성이 쉽고 내 자녀와 관련된 정보를 쉽게 얻을 수 있어서 다른 대안에 비해 학교 홈페이지를 선호하고 있는 것으로 나타났 다. 그럼에도 불구하고 내 자녀와 관련된 또 다른 정보는 $\mathrm{NEIS}$ 를 통해 이중으로 제공받는 셈이 된다. 따라서 인터넷 및 정보처리 기술의 발전과 더불어 NEIS를 통해 얻을 수 있는 정보를 학교 홈페이지와 일원화하여 제공할 수 있는 방법에 대해서도 연구가 이루어질 필요가 있다.

교육과정에 있어서 학부모의 역할은 중요하다. 가정에서 자녀의 교육을 책임질 뿐만 아니라 공교육의 원활한 운영을 위한 세금도 납부하고 있다. 따라서 NEIS의 학부모서비스에
서 최대 이해관계자인 학부모의 요구수렴은 매우 중요한 과 정이 된다. 본 연구는 기존의 기술수용모형과 같이 인지된 유용성에 그치지 않고 비용, 위험 등과 같이 대국민서비스 의 장애요인까지 포함하는 다양한 학부모의 의견을 수렴함 으로써 학부모의 실질적이며 적극적인 교육 참여를 유도하 는데 기여할 것으로 기대된다.

\section{참 고 문 헌}

[1] 서울경제신문, "NEIS 오류로 석차 바뀐 고교생 2만 9,007명", 2011. 7.25 .

[2] 박상철, "내자녀 바로 알기 인터넷 학부모서비스의 교육적 효과 분석”, 교육인적자원부, 정책연구과제, 2006 - 이슈-16, 2006.

[3] NEIS 홈페이지, http://www.neis.go.kr

[4] 윤원로, 김명진, 임혜선, 오병진, 구연미, 유영은, “학부모서비스 활성화 방안(서비스의 질 개선 방안)”, 서울: 한국교육학술정보 원, 2007.

[5] 김수구, "나이스 학부모서비스 신청·승인 절차상에 나타나는 학 부모의 인식 고찰”, 교육행정학연구, 27(4), pp.139-164, 2009.

[6] 박정주, "학교 조직의 교육행정정보시스템(NEIS) 수용 요인에 관한 구조적 분석”, 교육행정학연구, 25(4), pp.215-236, 2007.

[7] 유정수, 백현기, "교육정보화를 통한 학부모 학교교육 참여 촉진 방안 연구”, 한국정보교육학회, 13(4), pp.433-441, 2009.

[8] Seddon, P. B., "A Respecification and Extension of the DeLone and McLean Model of IS Success," Information Systems Research, 8(3), pp.240-253, 1997.

[9] Goodhue, D. L. and Thompson, R. L., "Task- Technology Fit and Individual Performance," MIS Quarterly, 19(2), pp.213-236, 1995.

[10] Rai, A., Lang, S. S. and Welker, R. B., "Assessing the Validity of IS Success Models: An Empirical Test and Theoretical Analysis," Information Systems Research, 13(1), pp.50-69, 2002.

[11] Kim, S. S. and Son, J. Y., "Out of Dedication or Constraint? A Dual Model of Post Adoption Phenomena and its Empirical Test in the Context of Online Services," MIS quarterly, 33(1), pp.49-70, 2009.

[12] Bendapudi, N. and Berry, L. L., "Customers' Motivations for Maintaining Relationships with Service Providers," Journal of Retailing, 73(1), pp.15-37, 1997.

[13] Saaty, T. L., Decision Making with Dependence and Feedback: The Analytic Network Process, RWS Publications, Pittsburgh, PA, 1996.

[14] 한국정보화진흥원, “범정부 서비스 참조모형 2.0”, 2009.

[15] Davis, F. D., "Perceived usefulness, perceived ease of use, and user acceptance of information technology," MIS Quarterly, 13(3), pp.319-340, 1989.

[16] Davis, F. D., Bagozzi, R. P. and Warshaw, P. R., "User Acceptance of Computer Technology: A Comparison of Two Theoretical Models," Management Science, 35(8), pp.982-1003, 1989. 
[17] Taylor, S. and Todd, P., "Assessing IT Usage: The Role of Prior Experience,” MIS Quarterly, 19(4), pp.561-570, 1995.

[18] Szajna, B., "Empirical Evaluation of The Revised Technology Acceptance Model," Management Science, 42(1), pp.85-92, 1996.

[19] Venkatesh, V. and Davis, F. D., "A Model of The Antecedents of Perceived Ease of Use: Development and Test," Decision Sciences, 27(3), pp.451-481, 1996.

[20] Venkatesh, V. and Davis, F. D., "A Theoretical Extension of the Technology Acceptance Model: Four Longitudinal Field Studies," Management Science, 46(2), pp.186-204, 2000.

[21] 하영수, "전자정부구현에 대한 주민수용태도에 관한 연구 -Davis의 신기술 수용모형을 중심으로”, 한국지방자치학회보, 통권38호, 14(2), pp.257-274, 2002.

[22] 장원경, 김태균, "비자발적 환경의 회계정보시스템 수용에 관한 연구: TAM과 TPB를 이용하여”, 한국데이타베이스학회, 12(1), pp.173-189, 2005.

[23] 김준우, 문형도, "비자발적 사용 환경에서의 기술 수용모델 (TAM)에 관한 연구”, 한국경영정보학회 학술대회, pp.706-723, 2008.

[24] 김태구, "비자발적 수용환경의 호텔 프론트오피스시스템 이용 예측”, 한국관광학회, 관광학연구, 30(1), pp.129-150, 2006.

[25] Ajzen, I., "The Theory of Planned Behavior," Organizational Behavior and Human Decision Processes, 50, pp.179-211, 1991.

[26] Chen, P. Y. and Hitt, L. M., "Measuring Switching Costs and the Determinants of Customer Retention in Internet-Enabled Businesses: A Study of the Online Brokerage Industry," Information Systems Research, 13(3), pp.255-274, 2002.

[27] Thatcher, J. B. and George, J. F., "Commitment, Trust, and Social Involvement: An Exploratory Study of Antecedents to Web Shopper Loyalty," Journal of Organizational Computing and E-Commerce, 14(4), pp.243-268, 2004.

[28] Hamalainen, R. P. and Stepplinen, T. O., "The Analytic Network Process in Energy Policy Planning," SocioEconomic Planning Sciences, 20(6), pp.399-405, 1986.

[29] Mead, L. and Sarkis, J., "A Conceptual Model for Selection and Evaluating Third-party Reverse Logistics Provider," Supply Chain Management, 7(5), 283-295, 2002.
[30] 이용복, 서현수, 윤덕균, “ANP를 이용한 고객 지향적 마케팅 의사결정 모델 설계”, 품질경영학회지, 33(2), pp.32-40, 2005.

[31] Sarkis, J., "A Methodological Framework for Evaluating Environmentally Conscious Manufacturing Program", Computers and Industrial Engineering, 36(4), pp.793-810, 1999

[32] 김수구, "NEIS 교무업무시스템 활용 과정상의 장애요인 분석NEIS 지원서비스의 질의내용을 중심으로”, 교육연구논총, 29(1), pp.1-22, 2008.

[33] Sallis, J., Schools, parents and governors: A new approach to accountability, London: Routledge, 1988.

[34] 문창배, 고요섭, 손충기, 마지순, 조정원, 박정환, "교육주체간 상호작용을 고려한 구성주의 기반 학급운영시스템”, 한국콘텐 츠학회논문지, 10(3), pp.454-462, 2010.

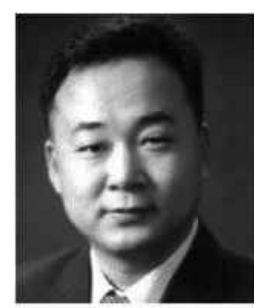

서 현 식

-mail : neokgb@dankook.ac.kr

2008년 단국대학교 경영정보학과(박사)

2009년 2011년 연세대학교 방송통신정책 연구센터 연구교수

현 재 단국대학교 시간강사

관심분야: 정보통신정책, $\mathrm{u}-\mathrm{Biz}$ 전략, 모바일 인터넷 광고 전략, 지식경영

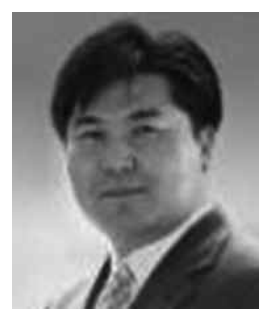

\section{송 인 국}

e-mail : iksong@dankook.ac.kr University of Tennessee at Martin, Computer Science (학사)

The George Washington University, Information Management (석사)

The George Washington University, Info, \& System Management (박사)

현 재 단국대학교 경영학부 부교수

관심분야: 공공기관 정보시스템, 정보기술정책, IT business 전략, 정보화 전략 등 